『道法會元』における護符分析支援システムの試作

\title{
○宇陀則彦（筑波大学）為沢ふみ（図書館情報大学） 松本浩一（筑波大学）二階堂善弘（茨城大学）
}

Charm Analysis Support System for "Dao-fa Hui-yuan" Research

Norihiko Uda Fumi Tamezawa Koichi Matsumoto and Yoshihiro Nikaido

This paper describes a charm analysis support system for "Dao-fa Hui-yuan" research. The system consists of a support function of name analysis of charms and a support function of parts analysis of ones. The name analysis support function provides KWIC analysis and $\mathrm{N}$-gram analysis. KWIC analysis support function performs order influence arrangement and reverse influence arrangement with the inputted character sequence as the starting point. $\mathrm{N}$-gram analysis support function displays $\mathrm{N}$-gram strings from the 1st place to the 50th place in order of frequency. Charm parts analysis support function manages the parts information which constitutes a charm.

\section{1. はじめに}

近年、多くの歴史資料が電子化され、コンピュータを利用した研究が活発に行われている。資 料が電子化されることにより、電子化資料ならではの研究利用の可能性が広がった。電子化資料 を対象に研究を行うためには使いやすい研究支援ツールが望まれる。本研究では研究対象として 『道法會元』を取り上げ、研究支援ツールを試作した。道法會元は道教における雷法の呪術儀式 を集成した文献で、護符が重要な意味を持っている[1]。護符はさらに複数の意味を持ったパーツ から構成され、また護符の名前も効果や意味を表す言葉から構成されている。これまで、護符の 構成については Dore[2]による研究があるが、詳細な構造や関係は明らかになっていない。そこ で、本研究では、道法會元の電子化実験[3]に引き続き、護符分析支援を行える機能を試作し、コ ンピュータを用いた道教資料研究の有効性を示す。

\section{2. 護符名分析支援機能}

\section{1 概要}

護符の名前は、護符の効果や意味を表している。図 1 に護符名の一例を示す。

\begin{tabular}{|c|c|c|}
\hline 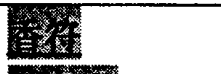 & S神符 & 天雷靃元 \\
\hline 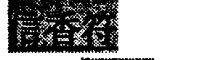 & zed 露符 & 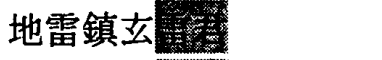 \\
\hline et & IIX) 寶章 & 水雷環運政 \\
\hline 散命雷霆 & 翡影通三界玉符 & 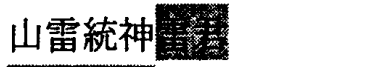 \\
\hline 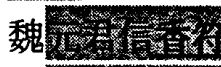 & 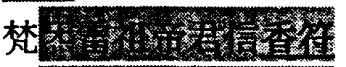 & 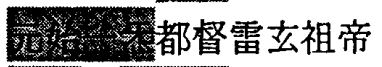 \\
\hline 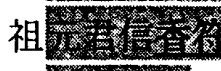 & 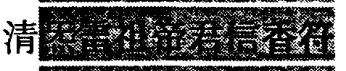 & 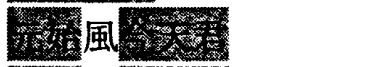 \\
\hline 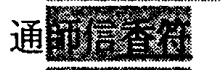 & 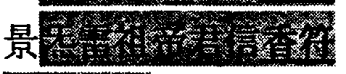 & \\
\hline 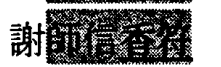 & 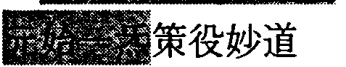 & $\cdots$ \\
\hline
\end{tabular}

図 1 : 護符名の例 
本研究では護符名の文字列の構造を分析し、他の言葉との組み合わせ、使われ方などを比較す る。

\section{$2.2 \mathrm{KWIC}$ 分析}

同じ文字列を含む護符名を集束させて表示する機能を実装した。図 2 にその例を示す。

一香符
-謝師信香符
-祖元君信香符
-清䵩雷祖帝君信香符
-祈晴心香符
-信香符
-通用信香符
-梵息雷祖帝君信香符
-魏元君信香符

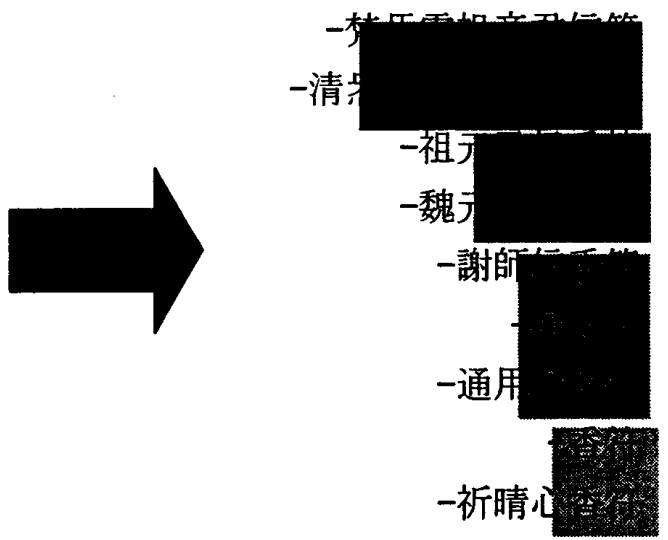

図 2 「香符」における段階的構造図

KWIC 分析機能の利点として次のようなことがあげられる。

(1)護符名の文法的・意味的構造が分かりやすく表示できる。

(2)護符画像とリンクすることにより名称的に構造が近い護符を比較できる。

\section{$2.3 \mathrm{~N} \cdot \mathrm{gram}$ 分析}

護符名の構造は同じ文字列が何度も使われることが多い。そこで、一度しか現れない文字列の 切り出しパターンよりも、何回も使われているパターンは護符において重要な言葉であると考え られる。そこで、N-gram で切り出した文字列を出現頻度順にソートし、切り出し語ごとに含む 護符名を分けて一覧表示させた。図 3 に $=1,2,3,4$ の結果を示す。

\begin{tabular}{|c|c|c|c|c|c|c|c|}
\hline 文字 & 回数 & 字 & 回数 & 文字 & 回 & 文字 & 回 \\
\hline 等 & 3346 & 聚 形 & 496 & 使 者 符 & 82 & 丞濟諸 項 & 62 \\
\hline & 1020 & 形 & 490 & $=+$ 四 & 72 & 齊 諸 項 真 & 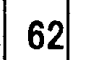 \\
\hline $2 x$ & 5 & 真 符 & 130 & 濟 諸 項 & 62 & 諸 項 真 符 & 6 \\
\hline 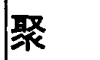 & 501 & 使 者 & 123 & 拯濟諸 & 62 & $二+$ 四厄 & \\
\hline 雷 & 4 & 神 & 117 & 諸 項 真 & 62 & 十四厄 符 & \\
\hline & 395 & 厄 符 & 111 & 項 真 符 & 62 & 解 二十四 & 4 \\
\hline 召 & . & 雷 符 & 105 & 信 香 符 & 52 & 雷 文天策 & \\
\hline 10 & 2 & 者 符 & 82 & 十四厄 & 48 & 元 始 一 穒 & \\
\hline & 239 & $=+$ & 82 & 解 二 + & 48 & 童 経 二十 & 2 \\
\hline & 20 & 十四 & 73 & 四厄符 & 48 & 経 二十四 & 2 \\
\hline
\end{tabular}

図 $3 \mathrm{~N}$ 文字列の出現頻度上位 10 件 
3. パーツ分析支援機能

3.1 パーツ分析

散形と聚形の情報を利用して、護符を複数のパーツに分解する。散形とはひとつの護符をパー ツに分解して解説している図のことである。全ての護符に散形があるわけではないが、散形があ る護符からパーツを確実に同定することにより、同定できるパーツを増やすことができる。

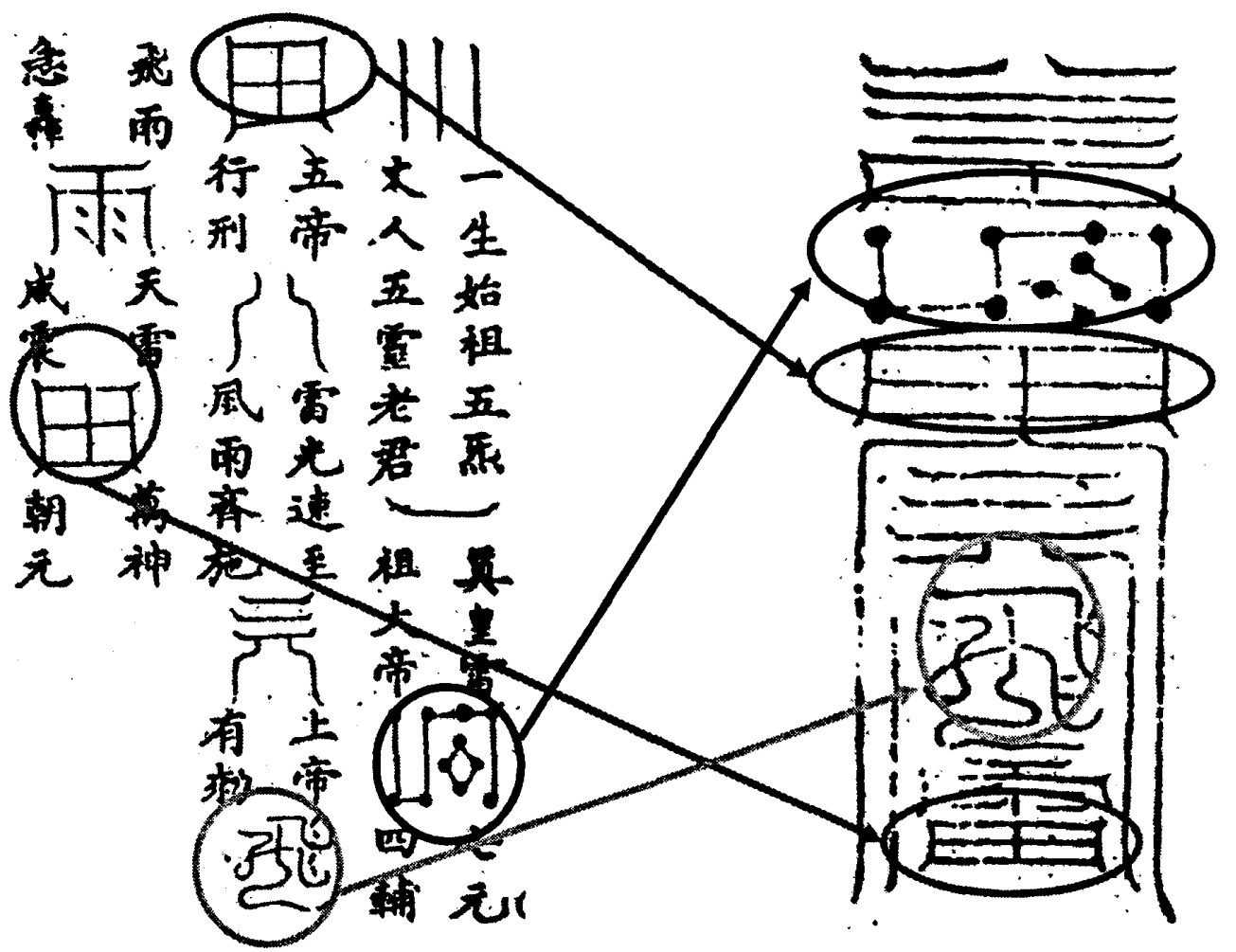

辰時飛龍將义鳩羅 (左)[散形]（右)[聚形]

図4 散形と聚形

図4においては、それぞれの護符に北斗七星をあらわすパーツと、「田」のようなパーツが含まれている のが分かる。同じ図形であるが、配置や描かれ方が変化している。一つの符の中に複数同じパーツが含 まれる場合もある。パーツは意味を持っており、個々の符の中での位置や、他のパーツとの繋がりによ って護符全体の意味を構成している。パーツの構成を分析することによって護符の意味的構造を明らか にできる可能性がある。

\section{2 パーツ情報付与}

パーツ分析を行うためには、多くのパーツ情報を管理する必要である。しかしながら、パーツ 情報を集積し整理する作業を人手で行うとしたら多くの労力を要する。入力後に誤りなどをチェ ックしやすく、パーツ情報の追加、削除、修正が容易な管理システムが求められる。そこで、本 システムでは、パーツ分析を支援する機能として XML 形式でパーツ情報を蓄積していく管理機 能を実現した。

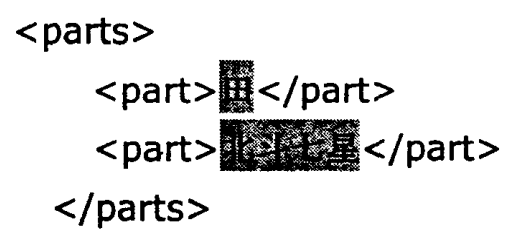

図 5 XMLによるパーツ情報付与 


\section{4. システムの実行例}

護符名分析支援機能、パーツ分析支援機能ともにWeb ブラウザから利用できる。図 6 は N-gram 分析結果を表示した例である。護符名から指定された数で切り出した語の頻度上位 50 件を左のフ レームに表示する。切り出し語の左には、対象とした名前ファイル中に切り出し語が出現した回 数を表示している。右のフレームには切り出し語を含む護符名の一覧が表示されている。切り出 し語をクリックすると、その切り出し語を含む護符名の先頭が右フレームの先頭に来る。護符名 一覽は切り出し語を緑色の文字で表示し、切り出し語ごとにグループ化して表示する。

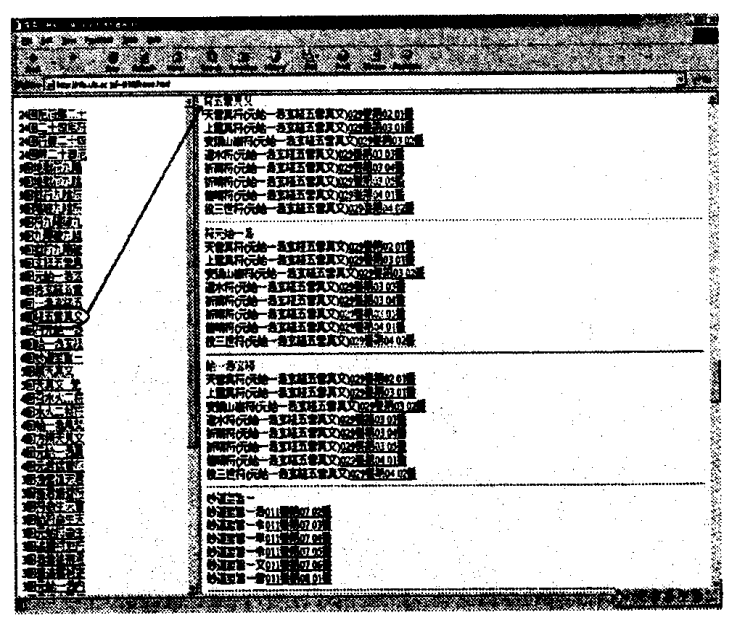

図 6 N-gram 表示

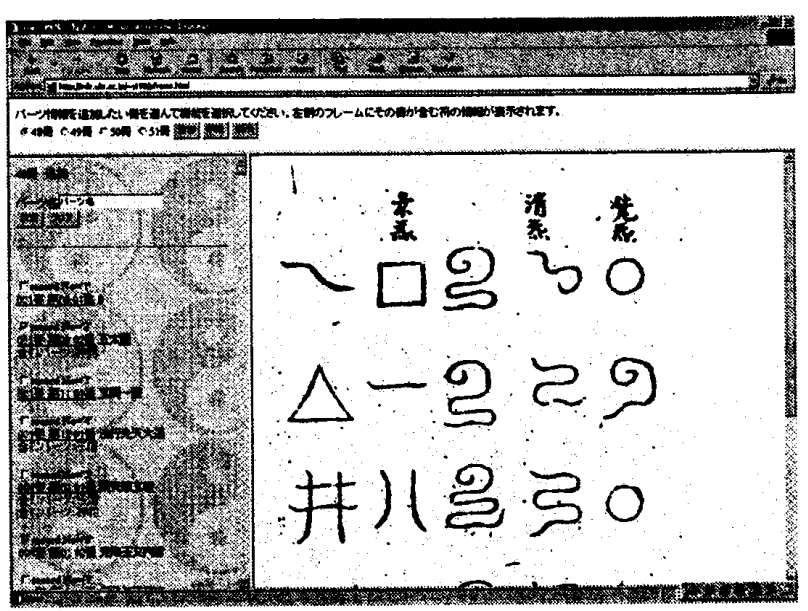

図 7 パーツ情報付与

図 7 はパーツ情報を付与するためのインタフェース画面である。左のフレームには護符名が表 示されており、それぞれチェックボックスを持たせている。パーツ情報を追加する場合は、入力 画面からパーツの名前とそれを含む護符を左フレームの一番上のテキストボックスから入力する。 護符名の横の位置情報からは護符画像にリンクが張ってあり、クリックすることで右画面に表示 される。護符の画像を見てパーツが含まれているかをチェックできる。全ての追加したい護符を チェックしたら、テキストボックスの下の「決定」ボタンを押してパーツ情報を保存する。

\section{5. おわりに}

本論文では、電子化された『道法會元』を対象に護符分析支援システムについて説明した。本 研究では、護符に関する情報を単なるデータをみなし、コンピュータによる機械的な情報処理を 行った点が特徴である。コンピュータ処理を行うことにより、人手による処理とは異なる結果が 期待できる。さらに、専門家による分析と組み合わせることにより、道教研究に新しい視点を提 供できる。

今後の展開としては、護符名の類似性、護符とパーツの相関、パーツ同士の相関、護符名とパ ーツ間の相関などを分析したいと考えている。

\section{参考文献}

[1] 松本浩一.『中国の呪術』。大修館書店, 2001.

[2] Henry Dore, M. Kennelly. Researches into Chinese superstitions Vol.1-3, 成文出版 1966.

[3] 林宏美, 宇陀則彦, 松本浩一, 二階堂善弘. 道教資料『道法會元』の電子化実験. 情報知識 学会誌 Vol.11, No.4, p.36-45 2001. 